\title{
Dietary Forage and Nonfiber Carbohydrate Contents Influence B-Vitamin Intake, Duodenal Flow, and Apparent Ruminal Synthesis in Lactating Dairy Cows
}

\author{
E. C. Schwab, ${ }^{\star}$ C. G. Schwab,† R. D. Shaver, ${ }^{\star 1}$ C. L. Girard,‡ D. E. Putnam,§ \\ and N. L. Whitehouse† \\ *Department of Dairy Science, University of Wisconsin, Madison 53706 \\ †Department of Animal and Nutritional Sciences, University of New Hampshire, Durham 03824 \\ $\ddagger$ Agriculture and Agri-Food Canada, Dairy and Swine Research \& Development Centre, \\ Lennoxville, QC, Canada J1M 1 Z3 \\ §Balchem Encapsulates, New Hampton, NY 10958
}

\begin{abstract}
The objective of this experiment was to quantify intakes, duodenal flows, and ruminal apparent synthesis (AS) of B-vitamins in lactating dairy cows fed diets varying in forage and nonfiber carbohydrate (NFC) contents. Eight (4 primiparous and 4 multiparous) ruminally and duodenally cannulated Holstein cows were assigned to 4 dietary treatments in a replicated 21-d period, $4 \times 4$ Latin square design with a $2 \times 2$ factorial treatment arrangement. Diets, fed as TMR, contained (DM basis) 2 levels of forage (35 and 60\%) and 2 levels of NFC (30 and 40\%). The forage portion of the diets contained 50\% corn silage, 33\% alfalfa hay, and $17 \%$ grass hay. Soybean hulls and beet pulp (2:1) and corn meal and ground barley (2:1) were included to achieve desired NFC concentrations. No supplemental B-vitamins were fed. B-vitamin AS was calculated as the amount of a specific B-vitamin flowing to the duodenum minus its daily orts-corrected intake. Dry matter and organic matter intakes were higher for cows fed the $35 \%$ forage diets and the $40 \%$ NFC diets. Increasing dietary forage content decreased ruminal AS of pyridoxine, folic acid, and $\mathrm{B}_{12}$. Increasing dietary NFC content increased ruminal AS of nicotinic acid, nicotinamide, niacin, pyridoxal, $\mathrm{B}_{6}$, and folic acid but decreased AS of $\mathrm{B}_{12}$. Across diets, amounts of $\mathrm{B}$-vitamins synthesized were highest for niacin, followed by riboflavin, $B_{12}$, thiamin, $B_{6}$, and folic acid. Biotin AS values were negative for all diets, suggesting either no ruminal synthesis or that destruction by ruminal microflora was greater than synthesis. B-vitamin intake, duodenal flow, and ruminal synthesis are influenced by dietary forage and NFC contents.
\end{abstract}

Received June 17, 2005.

Accepted August 17, 2005.

${ }^{1}$ Corresponding author: rdshaver@wisc.edu
Key words: B-vitamin, ruminal synthesis, duodenal flow, lactating cow

\section{INTRODUCTION}

Historical B-vitamin research identified that alteration of dietary forage to concentrate ratios (Conrad and Hibbs, 1954), dietary CP source (Hollis et al., 1954), and corn grain processing (Hayes et al., 1966) in ruminating calves, sheep, and steers, respectively, altered ruminal B-vitamin concentrations. Other studies in sheep (Sutton and Elliot, 1972) and steers (Miller et al., 1986; Zinn et al., 1987) indicated dietary effects on amounts of B-vitamins either consumed, flowing to the duodenum, or ruminally synthesized; amounts flowing to the duodenum generally exceeded B-vitamin intakes. Using lactating dairy cattle, Breves et al. (1981) varied ruminal $\mathrm{OM}$ digestion and duodenal microbial $\mathrm{N}$ flow through dietary interventions to study duodenal thiamin flow. Daily duodenal thiamin flow was related to daily microbial $\mathrm{N}$ flow $\left(\mathrm{r}^{2}=0.85\right)$ and amounts of $\mathrm{OM}$ digested in the total tract $\left(\mathrm{r}^{2}=0.87\right)$.

Past B-vitamin research led to the general dogma that dietary supply and ruminal synthesis are sufficient to meet dairy cow requirements (NRC, 2001). Although ruminal B-vitamin synthesis appears to be sufficient to prevent clinical deficiencies in most situations, supplementing dietary thiamin (Shaver and Bal, 2000), biotin (Zimmerly and Weiss, 2001; Majee et al., 2003), niacin (French, 2004), and folic acid (Girard and Matte, 1998) increased lactation performance. However, in other studies, lactation performance was not improved by supplemental folic acid (Girard et al., 2005), niacin (NRC, 2001), or biotin (Rosendo et al., 2004). Possible reasons for lack of consistent responses to B-vitamin supplementation are numerous, but a potentially important factor is variable amounts of ruminally synthesized B-vitamins. Data regarding amounts of B-vitamins flowing to the duodenum or ruminally synthesized 
in lactating dairy cows are limited. The NRC (2001) estimates of ruminal B-vitamin synthesis in lactating cows were extrapolated from steer data of Miller et al. (1986) and Zinn et al. (1987) as lactating dairy cow data were not available. The objective of this experiment was to quantify B-vitamin intakes, duodenal flows, and apparent synthesis in lactating dairy cows fed production diets differing in forage and NFC concentrations and to relate B-vitamin apparent synthesis to nutrient intakes and digestion parameters.

\section{MATERIALS AND METHODS}

\section{Experimental Design and Treatment Diets}

Four primiparous ( $574 \pm 59 \mathrm{~kg}$ of BW) and 4 multiparous ( $651 \pm 67 \mathrm{~kg}$ of $\mathrm{BW})$ lactating Holstein dairy cows were fitted with ruminal cannulas $(10.2 \mathrm{~cm}$; Bar Diamond, Inc., Parma, ID) and open gutter-style plastisol duodenal cannulas before the start of the experiment with surgical procedures as described by Putnam et al. (1997). Four cows (2 primiparous and 2 multiparous) were cannulated while nonlactating; the remaining cows were cannulated during mid to late lactation. All experimental procedures were approved by the Institutional Animal Care and Use Committee, University of New Hampshire.

The experimental design was a replicated $4 \times 4$ Latin square. Treatments were in a $2 \times 2$ factorial arrangement, and periods were $21 \mathrm{~d}$. The first $15 \mathrm{~d}$ were used for diet adaptation. The experiment was conducted from February to May 2003. Cows were assigned to concurrently run squares based on similar DIM [204 \pm 31 and $33 \pm 11$ DIM (mean \pm SD)], respectively, for squares 1 and 2); each square contained 2 multiparous and 2 primiparous cows. The 4 treatment diets (Tables 1 and 2) contained 35 or $60 \%$ forage and 30 or $40 \%$ NFC (DM basis). The forage portion of all diets contained (DM basis) 50\% corn silage, 33\% alfalfa hay, and $17 \%$ grass hay. Soybean hulls and beet pulp (2:1) and corn and barley (2:1) were used to formulate for desired NFC concentrations. Soybean meal, blood meal, and urea were used in formulations to meet RDP and RUP recommendations (NRC, 2001). Amounts of the vitamin-mineral premix and calcium monophosphate were adjusted (Table 1) to achieve desired $\mathrm{Ca}$ and $\mathrm{P}$ concentrations (Table 3 ).

\section{Feeding and Management}

Diets were mixed once daily at $1600 \mathrm{~h}$ in a drum-type mixer (Data Ranger, American Calan Inc., Northwood, $\mathrm{NH}$ ). Alfalfa and grass hays were chopped (Teagle Tomahawk model 5050, Teagle Machinery Ltd., Blackwater, Truro, UK) before incorporation into the TMR.
Table 1. Ingredient composition of the diets

\begin{tabular}{|c|c|c|c|c|}
\hline \multirow[b]{2}{*}{ Ingredient } & \multicolumn{4}{|c|}{$\operatorname{Diets}^{1}$} \\
\hline & $35-30$ & $35-40$ & $60-30$ & $60-40$ \\
\hline Forages & \multicolumn{4}{|c|}{ \% of $\mathrm{DM}$} \\
\hline Corn silage & 17.5 & 17.5 & 30.0 & 30.0 \\
\hline Alfalfa hay & 11.7 & 11.7 & 20.0 & 20.0 \\
\hline Grass hay & 5.8 & 5.8 & 10.0 & 10.0 \\
\hline \multicolumn{5}{|l|}{ Concentrates } \\
\hline Corn (fine ground) & 0.0 & 15.9 & 0.0 & 14.8 \\
\hline Barley (ground) & 0.0 & 8.0 & 0.0 & 7.4 \\
\hline Soybean hulls & 34.0 & 17.6 & 18.7 & 2.7 \\
\hline Beet pulp & 17.0 & 8.8 & 9.3 & 1.4 \\
\hline Soybean meal & 10.2 & 9.6 & 6.7 & 6.9 \\
\hline Blood meal & 0.0 & 0.6 & 1.8 & 2.2 \\
\hline Fat $^{2}$ & 1.6 & 1.6 & 1.6 & 1.6 \\
\hline Urea & 0.2 & 0.2 & 0.0 & 0.0 \\
\hline Smartamine $\mathrm{M}^{3}$ & 0.07 & 0.06 & 0.08 & 0.07 \\
\hline Vitamin-mineral premix ${ }^{4}$ & 1.5 & 2.7 & 1.4 & 3.0 \\
\hline Calcium monophosphate & 0.5 & 0.2 & 0.4 & 0.1 \\
\hline
\end{tabular}

${ }^{1} 35-30=35 \%$ forage $-30 \%$ NFC, $35-40=35 \%$ forage $-40 \%$ NFC, $60-30=60 \%$ forage $-30 \%$ NFC, and $60-40=60 \%$ forage $-40 \%$ NFC, where NFC was calculated by difference: $100-[C P+(\mathrm{NDF}-\mathrm{NDICP})$ + fat + ash]. NDICP $=$ Neutral detergent insoluble CP.

${ }^{2}$ Megalac, Church and Dwight Co., Inc., Princeton, NJ.

${ }^{3}$ Adisseo, Alpharetta, GA.

${ }^{4}$ Vitamin-mineral mix contained (\% DM): $10 \% \mathrm{Ca}, 8 \% \mathrm{Mg}, 2.5 \% \mathrm{~S}$, $15.2 \% \mathrm{Na}, 0.2 \% \mathrm{Zn}, 0.2 \% \mathrm{Mn}, 418 \mathrm{mg}$ of $\mathrm{Cu} / \mathrm{kg}, 70.4 \mathrm{mg}$ of Co/kg, $23.5 \mathrm{mg}$ of I/kg, $10.5 \mathrm{mg}$ of Se/kg, 65,300 IU of vitamin $\mathrm{A} / \mathrm{kg}, 15,100$ IU of vitamin D/kg, and $249 \mathrm{IU}$ of vitamin $\mathrm{E} / \mathrm{kg}$.

Diets were fed for ad libitum intake; amounts offered and refused were recorded daily to maintain approximately 5\% orts. Approximately $70 \%$ of the daily feed allotment was fed following mixing; the remainder was stored in individual $130-\mathrm{L}$ plastic refuse containers and was fed the following morning at $0400 \mathrm{~h}$. Because of differences in diet composition, cows were acclimated to the dietary treatments during the first $2 \mathrm{~d}$ (4 feedings) of each period. At each feeding during the acclimation period, approximately equal proportions of the previous and new treatment diets were combined and fed. Cows were housed in individual tie stalls, had free access to water, and were milked at 0400, 1200, and $2000 \mathrm{~h}$.

All dry dietary ingredients were stored individually in bins or bags, and corn silage was stored in a bunker silo. Soybean hulls and shredded beet pulp were delivered as a mix. Grass hay, ground corn, blood meal, soybean meal, fat, urea, Smartamine M (Adisseo USA, Inc., Alpharetta, GA), and vitamins and minerals fed throughout the experiment were each from a single batch delivered before the start of the experiment. The alfalfa hay, ground barley, and soybean hull-beet pulp mix were each from 2 deliveries received at the beginning of the experiment and before the start of period 4. Individual samples of beet pulp and soybean hulls accompanied each delivery. At the beginning of each 
Table 2. Nutrient composition of feeds

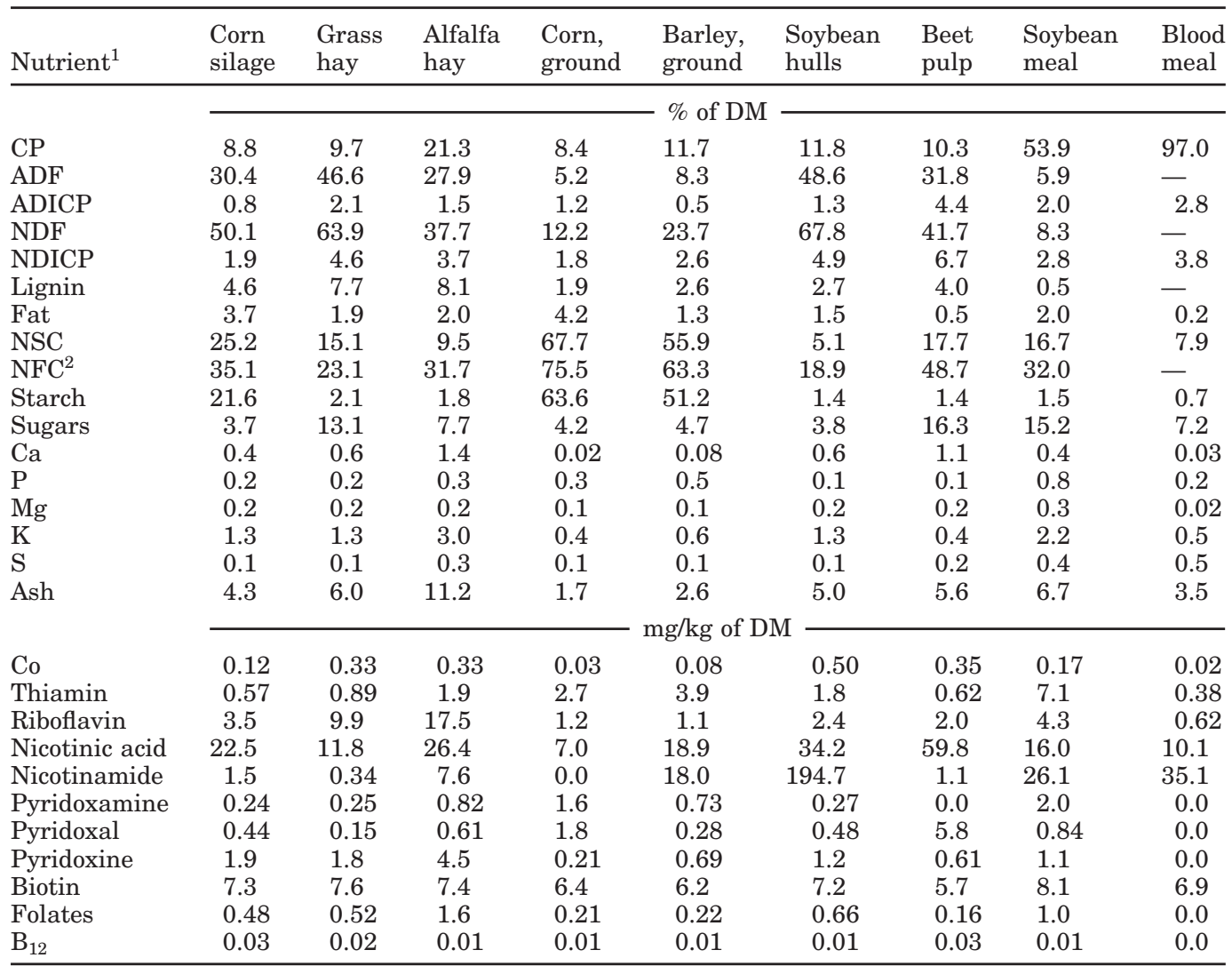

${ }^{1} \mathrm{ADICP}=$ Acid detergent insoluble $\mathrm{CP}$; NICP = neutral detergent insoluble $\mathrm{CP}$; NSC = nonstructural carbohydrate.

${ }^{2} \mathrm{NFC}$ calculated by difference: $100-[\mathrm{CP}+(\mathrm{NDF}-\mathrm{NDICP})+$ fat + ash $]$.

period appropriate proportions of fat, urea, Smartamine $\mathrm{M}$, calcium monophosphate, and vitamin-mineral mix were blended on location using a rotary mineral mixer. No supplemental B-vitamins were fed.

Chromic oxide and ammonia ${ }^{15} \mathrm{~N}\left(\left[{ }^{15} \mathrm{NH}_{4}\right]^{2} \mathrm{SO}_{4}\right.$, $10.6 \%$ enriched; Isotec, Miamisburg, $\mathrm{OH}$ ) were used as digesta and microbial $\mathrm{N}$ flow markers, respectively. Separate gelatin capsules (0.5 oz., Tropac, Inc., Fairfield, $\mathrm{NJ})$ containing $\mathrm{Cr}_{2} \mathrm{O}_{3}(7 \mathrm{~g})$ and $\left({ }^{15} \mathrm{NH}_{3}\right)_{2} \mathrm{SO}_{4}(3.33$ g) were dosed via the ruminal cannula at 0400,1200 , and $2000 \mathrm{~h}$ on d 6 to 20 and 13 to 20 , respectively. A 5 -g priming dose of $\left({ }^{15} \mathrm{NH}_{4}\right)_{2} \mathrm{SO}_{4}$ was also given on $\mathrm{d}$ 13 at $0400 \mathrm{~h}$.

\section{Data and Sample Collection}

Feed intakes were recorded daily; orts were weighed before the 1600-h feeding. Measurements of DMI taken on d 16 to 20 of each period were used in the statistical analysis. To adjust for changes in ingredient DM, samples of dry feeds were collected on d 12 of each period and dried at $55^{\circ} \mathrm{C}$ for $48 \mathrm{~h}$ in a forced-air oven. Corn silage DM was determined at least twice weekly (depending on weather conditions) by microwave oven to adjust for changes in DM content. Samples of all feeds (except soybean hulls and beet pulp) were collected at the beginning of wk 3 of each period and dried at $55^{\circ} \mathrm{C}$ for $48 \mathrm{~h}$ in a forced-air oven. All feeds were ground to pass a 1-mm Wiley mill screen (Arthur H. Thomas, Philadelphia, PA) and composited by type for nutrient analysis. Ort samples were collected on d 16 to 20 of each period, dried at $55^{\circ} \mathrm{C}$ for $48 \mathrm{~h}$ in a forced-air oven, ground to pass a 1-mm Wiley mill screen, and composited by cow within period for nutrient analysis.

Milk yields were collected from each milking on d 14 to 20. Milk samples were collected from 2 consecutive 1200-, 2000-, and 0400-h milkings on d 15 to 17. Samples from each of the 3 milkings were composited proportionally by yield and preserved with 2-bromo-2nitropropane-1, 3-diol.

Ruminal fluid was sampled at 0600, 1000, and 1400 $\mathrm{h}$ on d 19 and at 0330,0800 , and $1200 \mathrm{~h}$ on d 20 of each period. Rumen fluid samples (approximately 600 
Table 3. Nutrient composition of consumed diets

\begin{tabular}{|c|c|c|c|c|}
\hline \multirow[b]{2}{*}{ Nutrient } & \multicolumn{4}{|c|}{$\operatorname{Diet}^{1}$} \\
\hline & $35-30$ & $35-40$ & $60-30$ & $60-40$ \\
\hline DM, \% as-fed & 58.5 & 57.5 & 54.3 & 54.3 \\
\hline \multirow[t]{2}{*}{$\mathrm{NE}_{\mathrm{L}}, \mathrm{Mcal} / \mathrm{kg}$ of $\mathrm{DM}^{2}$} & 1.41 & 1.52 & 1.40 & 1.51 \\
\hline & \multicolumn{4}{|c|}{$\%$ of DM - } \\
\hline $\mathrm{OM}$ & 92.0 & 92.3 & 91.7 & 91.4 \\
\hline $\mathrm{CP}$ & 16.4 & 16.2 & 16.6 & 16.3 \\
\hline $\mathrm{ADF}$ & 33.8 & 24.3 & 31.5 & 22.2 \\
\hline NDF & 47.4 & 36.9 & 45.3 & 34.8 \\
\hline NDICP & 4.1 & 3.2 & 3.6 & 2.7 \\
\hline NFC & 29.1 & 39.2 & 29.8 & 38.9 \\
\hline NSC & 13.1 & 26.1 & 14.9 & 27.3 \\
\hline Starch & 5.2 & 18.9 & 7.7 & 20.7 \\
\hline Sugars & 8.0 & 7.2 & 7.2 & 6.6 \\
\hline Lignin & 3.8 & 3.6 & 4.6 & 4.3 \\
\hline Fat & 3.1 & 3.6 & 3.5 & 3.9 \\
\hline $\mathrm{Ca}$ & 1.1 & 1.0 & 1.1 & 1.0 \\
\hline $\mathrm{P}$ & 0.35 & 0.36 & 0.36 & 0.36 \\
\hline $\mathrm{Mg}$ & 0.34 & 0.39 & 0.31 & 0.40 \\
\hline $\mathrm{K}$ & 1.4 & 1.2 & 1.6 & 1.4 \\
\hline \multirow[t]{2}{*}{$\mathrm{S}$} & 0.20 & 0.22 & 0.21 & 0.24 \\
\hline & \multicolumn{4}{|c|}{ - $\mathrm{mg} / \mathrm{kg}$ of $\mathrm{DM}$} \\
\hline $\mathrm{Co}^{3}$ & 1.3 & 1.9 & 1.2 & 2.1 \\
\hline Thiamin & 1.7 & 2.1 & 1.5 & 1.9 \\
\hline Riboflavin & 4.6 & 4.3 & 6.2 & 5.9 \\
\hline Niacin & 94.8 & 59.7 & 65.6 & 29.5 \\
\hline Nicotinic acid & 29.1 & 22.0 & 25.5 & 18.3 \\
\hline Nicotinamide & 65.7 & 37.7 & 40.1 & 11.2 \\
\hline $\mathrm{B}_{6}$ & 3.2 & 3.2 & 3.2 & 3.2 \\
\hline Pyridoxamine & 0.4 & 0.7 & 0.4 & 0.7 \\
\hline Pyridoxal & 1.3 & 1.1 & 0.9 & 0.7 \\
\hline Pyridoxine & 1.5 & 1.4 & 1.9 & 1.8 \\
\hline Biotin & 6.3 & 6.4 & 6.8 & 6.8 \\
\hline Folates & 0.6 & 0.5 & 0.7 & 0.6 \\
\hline Vitamin $B_{12}$ & 0.02 & 0.01 & 0.02 & 0.02 \\
\hline
\end{tabular}

${ }^{1} 35-30=35 \%$ forage $-30 \% \mathrm{NFC}, 35-40=35 \%$ forage $-40 \% \mathrm{NFC}$, $60-30=60 \%$ forage $-30 \%$ NFC , and $60-40=60 \%$ forage $-40 \%$ NFC, where NFC calculated by difference: $100-[\mathrm{CP}+(\mathrm{NDF}-\mathrm{NDICP})+$ fat + ash]. NDICP $=$ neutral detergent insoluble CP.

${ }^{2}$ Calculated from NRC (2001).

${ }^{3}$ Cobalt content not orts-corrected.

$\mathrm{mL}$ total) were collected from the caudal and distal areas of the medial and ventral rumen into a $1.2-\mathrm{L}$ tubulated polypropylene flask using manual vacuum through a $1.3-\mathrm{cm}$ polyvinyl chloride pipe. Following manual mixing, a subsample (approximately $200 \mathrm{~mL}$ ) was immediately filtered through 4 layers of cheesecloth, and $\mathrm{pH}$ was measured. Duplicate 1-mL samples were acidified with $20 \mu \mathrm{L}$ of $50 \% \mathrm{H}_{2} \mathrm{SO}_{4}$ and frozen at $-20^{\circ} \mathrm{C}$ until prepared and analyzed for VFA. Separate 40-mL samples were transferred to polypropylene centrifuge tubes containing $2.4 \mathrm{~mL}$ of $6 \mathrm{~N} \mathrm{HCl}$ and frozen at $-20^{\circ} \mathrm{C}$ until $\mathrm{NH}_{3}$ analysis.

Samples of ruminal digesta were collected immediately following ruminal fluid sampling. Ruminal digesta (approximately $2 \mathrm{~L}$ per sampling time) were collected from 9 locations within the rumen, including 3 samples each from the dorsal, medial, and ventral ar- eas. Digesta samples were homogenized in a 3.8-L commercial blender (Waring Products Division, New Hartford, CT) for $1 \mathrm{~min}$ on low (16,000 rpm). Digesta were manually squeezed through one layer of 59- $\mu \mathrm{m}$ Dacron mesh (Sefar America, Inc., Briar Cliff Manor, NY) using a 33.1-L bucket with squeezing basket (Rubbermaid Home Products, Fairlawn, OH), and 1.5 L of strained rumen fluid was retained in 2-L polyethylene bottles containing $15 \mathrm{~mL}$ of $50 \% \mathrm{H}_{2} \mathrm{SO}_{4}$. Rumen bacteria were isolated by differential centrifugation as described by Whitehouse et al. (1991). Microbial pellets were lyophilized then ground using a commercial coffee bean grinder (Gloria Jeans, Irvine, CA). Rumen bacteria were isolated on d 9 of each period for background ${ }^{15} \mathrm{~N}$ analysis.

Duodenal digesta samples (500 $\mathrm{mL}$ per sampling) were collected every $3 \mathrm{~h}$ from d 16 to 19 with sampling advanced $1 \mathrm{~h} / \mathrm{d}$ such that 24 samples were taken for each cow each period, representing every $1 \mathrm{~h}$ of a 24 $\mathrm{h}$ period. Removal of the duodenal cannula plug often resulted in an initial surge of duodenal digesta. Digesta from an initial surge was discarded; only digesta from subsequent flows were retained $(500 \mathrm{~mL}$ per sampling time), composited by cow within period, and frozen at $-20^{\circ} \mathrm{C}$. Digesta composites were thawed during the first week of the following period and homogenized (3.8-L Waring blender) in their entirety while still partially frozen. Composites were continually poured between containers during subsampling to maintain homogeneity. A 1.2-L subsample was lyophilized and ground to pass through a $40-\mu \mathrm{m}$ screen before nutrient analysis. Approximately $250 \mathrm{~mL}$ of digesta was strained (59- $\mu \mathrm{m}$ Dacron mesh), and duplicate $50-\mathrm{mL}$ samples were retained and frozen $\left(-20^{\circ} \mathrm{C}\right)$ until $\mathrm{NH}_{3}$ analysis. Duodenal digesta were collected on d 9 of each period for background ${ }^{15} \mathrm{~N}$ analysis.

\section{Analytical Procedures}

Milk composites were analyzed by infrared analysis for fat and true protein by (DairyOne Milk Laboratories, Ithaca, NY) using a Foss MilkoScan 4000 (Foss Electric, Hillerød, Denmark). Feeds and composited orts were analyzed for OM (AOAC, 1990) and CP, ADF, acid detergent insoluble $\mathrm{CP}, \mathrm{NDF}$, neutral detergent insoluble CP, lignin, fat, nonstructural carbohydrates, starch, sugars, and minerals (Table 2) using wet chemistry (DairyOne Forage Laboratories, Ithaca, NY) procedures. Starch was analyzed using a YSI 2700 Select Biochemistry Analyzer (YSI, Inc., Yellow Springs, $\mathrm{OH}$ ), and sugars were as described by Hall et al. (1999). Nonfiber carbohydrate was calculated by difference: $100-[\mathrm{CP}+(\mathrm{NDF}-\mathrm{NDICP})+$ fat + ash $]$ where NDICP $=$ neutral detergent insoluble CP. Feeds were 
Table 4. Intake, duodenal flow, and ruminal digestibility of dietary nutrients and duodenal flow of $\mathrm{N}$ fractions in lactating cows fed diets containing either 35 or $60 \%$ forage and 30 or $40 \% \mathrm{NFC}^{1}$

\begin{tabular}{|c|c|c|c|c|c|c|c|c|}
\hline \multirow[b]{2}{*}{ Item } & \multicolumn{4}{|c|}{ Diet $^{2}$} & \multirow[b]{2}{*}{ SEM } & \multicolumn{3}{|c|}{ Effect } \\
\hline & $35-30$ & $35-40$ & $60-30$ & $60-40$ & & Forage & $\mathrm{NFC}$ & $\mathrm{INT}^{3}$ \\
\hline & & & & & & 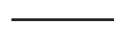 & $-P-$ & 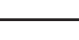 \\
\hline \multicolumn{9}{|l|}{ DM } \\
\hline Intake, $\mathrm{kg} / \mathrm{d}$ & 21.3 & 22.2 & 18.1 & 19.8 & 1.3 & $<0.001$ & 0.06 & 0.57 \\
\hline Flow, kg/d & 15.1 & 15.5 & 12.5 & 14.8 & 0.8 & 0.004 & 0.01 & 0.08 \\
\hline $\mathrm{NM}^{3}$ flow, $\mathrm{kg} / \mathrm{d}$ & 11.3 & 11.5 & 9.6 & 10.9 & 0.6 & 0.02 & 0.11 & 0.18 \\
\hline \multicolumn{9}{|l|}{ Truly digested } \\
\hline $\mathrm{kg} / \mathrm{d}$ & 9.9 & 10.7 & 8.5 & 8.9 & 0.9 & 0.02 & 0.35 & 0.78 \\
\hline$\%$ intake & 46.3 & 47.8 & 46.3 & 43.8 & 2.3 & 0.39 & 0.81 & 0.40 \\
\hline \multicolumn{9}{|l|}{$\mathrm{OM}$} \\
\hline Intake, $\mathrm{kg} / \mathrm{d}$ & 19.6 & 20.5 & 16.6 & 18.1 & 1.2 & $<0.001$ & 0.07 & 0.61 \\
\hline Flow, kg/d & 12.0 & 12.6 & 10.1 & 12.1 & 0.8 & 0.02 & 0.009 & 0.14 \\
\hline NM flow, ${ }^{4} \mathrm{~kg} / \mathrm{d}$ & 8.4 & 8.7 & 7.3 & 8.4 & 0.6 & 0.09 & 0.10 & 0.32 \\
\hline \multicolumn{9}{|l|}{ Truly digested } \\
\hline $\mathrm{kg} / \mathrm{d}$ & 11.1 & 11.7 & 9.3 & 9.7 & 0.8 & 0.008 & 0.44 & 0.88 \\
\hline$\%$ intake & 56.9 & 57.1 & 56.0 & 52.8 & 2.2 & 0.26 & 0.51 & 0.45 \\
\hline \multicolumn{9}{|l|}{$\mathrm{NDF}$} \\
\hline Intake, kg/d & 10.1 & 8.2 & 8.2 & 6.9 & 0.5 & $<0.001$ & $<0.001$ & 0.24 \\
\hline Flow, kg/d & 6.1 & 5.5 & 5.0 & 5.1 & 0.4 & 0.001 & 0.26 & 0.10 \\
\hline \multicolumn{9}{|l|}{ Digested } \\
\hline $\mathrm{kg} / \mathrm{d}$ & 4.0 & 2.6 & 3.3 & 1.8 & 0.3 & 0.03 & $<0.001$ & 0.90 \\
\hline$\%$ intake & 39.4 & 31.3 & 39.8 & 25.6 & 3.2 & 0.41 & 0.003 & 0.34 \\
\hline \multicolumn{9}{|l|}{ Starch } \\
\hline Intake, $\mathrm{kg} / \mathrm{d}$ & 1.1 & 4.2 & 1.4 & 4.1 & 0.2 & 0.38 & $<0.001$ & 0.15 \\
\hline Flow, kg/d & 0.6 & 1.6 & 0.4 & 1.5 & 0.1 & 0.13 & $<0.001$ & 0.96 \\
\hline \multicolumn{9}{|l|}{ Digested } \\
\hline $\mathrm{kg} / \mathrm{d}$ & 0.5 & 2.5 & 1.0 & 2.6 & 0.2 & 0.09 & $<0.001$ & 0.17 \\
\hline$\%$ intake & 45.9 & 59.5 & 69.2 & 62.1 & 4.6 & 0.001 & 0.36 & 0.007 \\
\hline \multicolumn{9}{|l|}{$\mathrm{N}$} \\
\hline Intake, $\mathrm{g} / \mathrm{d}$ & 558 & 575 & 480 & 520 & 33.7 & 0.002 & 0.13 & 0.52 \\
\hline Flow, g/d & 605 & 585 & 505 & 569 & 37 & 0.03 & 0.36 & 0.09 \\
\hline $\mathrm{NH}_{3} \mathrm{~N}$ flow, g/d & 32.4 & 27.0 & 30.2 & 29.2 & 2.2 & 0.98 & 0.03 & 0.13 \\
\hline NANM N flow, ${ }^{5} \mathrm{~g} / \mathrm{d}$ & 230 & 201 & 197 & 182 & 17 & 0.10 & 0.16 & 0.65 \\
\hline \multicolumn{9}{|l|}{ Microbial N flow } \\
\hline $\mathrm{g} / \mathrm{d}$ & 342 & 357 & 279 & 359 & 27 & 0.15 & 0.03 & 0.13 \\
\hline $\mathrm{g} / \mathrm{kg}$ of $\mathrm{OMTD}^{6}$ & 31 & 31 & 31 & 39 & 2.0 & 0.07 & 0.07 & 0.04 \\
\hline \multicolumn{9}{|l|}{ Intake, $\mathrm{kg} / \mathrm{d}$} \\
\hline NFC & 6.2 & 8.7 & 5.4 & 7.7 & 0.5 & 0.001 & $<0.001$ & 0.76 \\
\hline Nonstructural carbohydrates & 2.8 & 5.8 & 2.7 & 5.4 & 0.3 & 0.20 & $<0.001$ & 0.38 \\
\hline Sugars & 1.7 & 1.6 & 1.3 & 1.3 & 0.1 & $<0.001$ & 0.04 & 0.28 \\
\hline
\end{tabular}

\footnotetext{
${ }^{1}$ Calculated by difference: $100-[\mathrm{CP}+(\mathrm{NDF}-\mathrm{NDICP})+$ fat + ash $]$. NDICP $=$ neutral detergent insoluble CP.

${ }^{2} 35-30=35 \%$ forage $-30 \%$ NFC, $35-40=35 \%$ forage $-40 \%$ NFC, $60-30=60 \%$ forage $-30 \%$ NFC, and $60-$ $40=60 \%$ forage $-40 \%$ NFC (DM basis), where NFC = non-fiber carbohydrates calculated by difference: 100

$-[\mathrm{CP}+(\mathrm{NDF}-\mathrm{NDICP})+$ fat + ash $] . \mathrm{NDICP}=$ neutral detergent insoluble $\mathrm{CP}$.

${ }^{3} \mathrm{INT}=$ Interaction of dietary forage and NFC content.

${ }^{4} \mathrm{NM}=$ Nonmicrobial.

${ }^{5} \mathrm{NANM}=$ Nonammonia, nonmicrobial N.

${ }^{6}$ OMTD $=$ OM Truly digested ruminally, corrected for duodenal microbial OM flow.
}

analyzed for Co at the University of Wisconsin-Madison Soil and Plant Analysis Laboratory by inductively coupled plasma mass spectrometry using a VG PlasmaQuad PQ2 Turbo Plus (Thermo Electron Corp., Waltham, MA).

Ruminal fluid was analyzed for VFA by GLC (Varian 2100, Sunnyvale, CA), and $\mathrm{pH}$ was measured using a portable $\mathrm{pH}$ meter (Orion model $230 \mathrm{~A}, \mathrm{pH}$ triode electrode, Orion Research, Inc., Boston, MA). Ammonia analysis was performed using a gas-ammonium electrode (Orion model 407A meter with 95-12 electrode; Orion Research, Inc.).

Duodenal digesta were analyzed for OM, CP, NDF, and starch (DairyOne). Duodenal Cr content was analyzed by inductively coupled plasma atomic emission spectrophotometry as described by Williams et al. 
Table 5. Ruminal $\mathrm{pH}, \mathrm{VFA}$, and $\mathrm{NH}_{3} \mathrm{~N}$ concentrations in lactating cows fed diets containing 35 or $60 \%$ forage and 30 or $40 \% \mathrm{NFC}^{1}$

\begin{tabular}{|c|c|c|c|c|c|c|c|c|}
\hline \multirow[b]{2}{*}{ Item } & \multicolumn{4}{|c|}{ Diet $^{2}$} & \multirow[b]{2}{*}{ SEM } & \multicolumn{3}{|c|}{ Effect } \\
\hline & $35-30$ & $35-40$ & $60-30$ & $60-40$ & & Forage & NFC & $\mathrm{INT}^{3}$ \\
\hline & & & & & & & $P$ & - \\
\hline $\mathrm{pH}^{\mathrm{a}, \mathrm{b}, \mathrm{c}}$ & 6.0 & 6.0 & 6.3 & 6.4 & 0.05 & $<0.001$ & 0.16 & 0.89 \\
\hline $0^{4}$ & 6.1 & 6.3 & 6.5 & 6.2 & 0.08 & & & \\
\hline 2 & 6.0 & 6.1 & 6.1 & 6.3 & 0.07 & & & \\
\hline 4 & 6.0 & 5.9 & 6.3 & 6.2 & 0.07 & & & \\
\hline 6 & 5.9 & 5.9 & 6.2 & 6.2 & 0.07 & & & \\
\hline 8 & 5.9 & 6.0 & 6.4 & 6.4 & 0.07 & & & \\
\hline 10 & 6.0 & 6.0 & 6.4 & 6.4 & 0.07 & & & \\
\hline Total VFA, $m M^{\mathrm{a}, \mathrm{b}}$ & 111.9 & 104.9 & 100.3 & 102.1 & 5.0 & 0.02 & 0.38 & 0.14 \\
\hline $0^{4}$ & 109.6 & 98.0 & 91.8 & 85.1 & 6.5 & & & \\
\hline 2 & 108.7 & 100.0 & 109.4 & 111.2 & 6.5 & & & \\
\hline 4 & 117.7 & 106.4 & 105.9 & 118.8 & 6.5 & & & \\
\hline 6 & 118.6 & 108.8 & 103.4 & 108.8 & 6.5 & & & \\
\hline 8 & 114.5 & 113.2 & 101.1 & 97.1 & 6.5 & & & \\
\hline 10 & 106.9 & 103.0 & 90.1 & 91.8 & 6.5 & & & \\
\hline \multirow[t]{2}{*}{$\mathrm{NH}_{3} \mathrm{~N}, \mathrm{mg} / \mathrm{dL}^{\mathrm{a}, \mathrm{b}}$} & 12.2 & 11.4 & 10.5 & 11.6 & 0.6 & 0.09 & 0.70 & 0.04 \\
\hline & \multicolumn{4}{|c|}{$\mathrm{mol} / 100 \mathrm{~mol}$} & & & & \\
\hline $\operatorname{Acetate}^{\mathrm{a}}(\mathrm{A})$ & 63.9 & 61.3 & 66.7 & 64.1 & 0.7 & $<0.001$ & $<0.001$ & 0.99 \\
\hline Propionate $^{\mathrm{a}, \mathrm{b}}(\mathrm{P})$ & 20.6 & 22.9 & 18.7 & 19.9 & 0.4 & $<0.001$ & $<0.001$ & 0.10 \\
\hline Butyrate $^{a}$ & 11.7 & 11.9 & 10.7 & 11.3 & 0.4 & 0.02 & 0.24 & 0.57 \\
\hline Others $^{5}$ & 3.8 & 3.9 & 3.8 & 4.7 & 0.2 & 0.05 & 0.02 & 0.07 \\
\hline $\mathrm{A}: \mathrm{P}^{\mathrm{a}, \mathrm{b}}$ & $3.1: 1$ & $2.7: 1$ & $3.6: 1$ & $3.3: 1$ & 0.1 & $<0.001$ & $<0.001$ & 0.61 \\
\hline \multirow{2}{*}{\multicolumn{9}{|c|}{$\begin{array}{l}{ }^{1} \text { Calculated by difference: } 100-[\mathrm{CP}+(\mathrm{NDF}-\mathrm{NDICP})+\text { fat }+ \text { ash }] \text {. NDICP }=\text { neutral detergent insoluble } \\
\mathrm{CP} \text {. }\end{array}$}} \\
\hline & & & & & & & & \\
\hline \multicolumn{9}{|c|}{${ }^{2} 35-30=35 \%$ forage $-30 \%$ NFC, $35-40=35 \%$ forage $-40 \%$ NFC, $60-30=60 \%$ forage $-30 \%$ NFC, and $60-$} \\
\hline \multicolumn{9}{|c|}{${ }^{3} \mathrm{INT}=$ Interaction of dietary forage and NFC content. } \\
\hline \multicolumn{9}{|c|}{${ }^{4}$ Hour relative to 0400 - $h$ feeding. } \\
\hline \multicolumn{9}{|c|}{${ }^{5}$ Others $=$ isobutyrate, isovalerate, valerate. } \\
\hline \multicolumn{9}{|c|}{${ }^{a}$ Repeated measures effect: $\mathrm{h}(P<0.01)$} \\
\hline \multicolumn{9}{|c|}{${ }^{\mathrm{b}}$ Repeated measures effect: forage $\times \mathrm{h}(P<0.05)$. } \\
\hline & & & (05) & & & & & \\
\hline
\end{tabular}

(1962) using a Varian Vista AX-CCD (Varian Instruments, Mulgrave, Australia). Duodenal samples were analyzed in triplicate for $\mathrm{DM}\left(100^{\circ} \mathrm{C}\right.$, forced-air oven to constant weight). Ammonia analysis was performed as described for ruminal fluid. Duodenal digesta and bacterial samples to be used for ${ }^{15} \mathrm{~N}$ analysis were placed in $8-\times 5$-mm tin capsules (EMAL-Tec USA, Mason, $\mathrm{OH})$, treated with $50 \mu \mathrm{L}$ of $\mathrm{K}_{2} \mathrm{CO}_{3}(10 \mathrm{~g} / \mathrm{L})$, and placed in a $60^{\circ} \mathrm{C}$ oven overnight to evaporate residual ammonia. Samples were analyzed for total $\mathrm{N}$ and ${ }^{15} \mathrm{~N}$ at the Stable Isotope Facility (University of California, Davis) by isotope ratio mass spectrophotometry using a Europa Scientific Integra (PDZ Europa, Cheshire, England).

Assays for feeds, orts, and duodenal digesta B-vitamin concentrations were developed by the laboratory of C. L. Girard and conducted as described by Santschi et al. (2005a). Thiamin, riboflavin, niacin (nicotinic acid and nicotinamide), and $\mathrm{B}_{6}$ (pyridoxamine, pyridoxal, and pyridoxine) were analyzed by HPLC. Biotin was analyzed by enzyme-linked immunosorbent assay. Pancreatic extract (pancreas acetone powder, bovine, Sigma, St. Louis, MO) was added to each sample to release bound biotin for analysis; samples were corrected for pancreatic extract biotin concentrations. Folates and true $\mathrm{B}_{12}$ were analyzed by radioassay as described by Girard et al. (1994) and Santschi et al. (2005a).

\section{Calculations and Statistical Analyses}

Apparent synthesis (AS) of B-vitamins was calculated as the daily amount of a specific B-vitamin flowing to the duodenum minus its daily orts-corrected intake. This calculation does not reflect net B-vitamin synthesis, as it ignores ruminal degradation, microbial use, or potential absorption across the rumen wall. Niacin AS and flow were calculated as the sum of nicotinic acid (NA) and nicotinamide (NAM). Vitamin $\mathrm{B}_{6}$ $\mathrm{AS}$ and flow were calculated as the sum of pyridoxamine (PAM), pyridoxal (PAL), and pyridoxine (PYR). 
All intake, duodenal flow, and production-related data were reduced to cow-period means $(\mathrm{n}=32)$ prior to statistical analysis. Data were analyzed as a replicated Latin square using the mixed procedure of SAS (2002). The model included period, square, forage, NFC, and forage $\times$ NFC interaction as fixed effects; cow within square was a random effect. Ruminal $\mathrm{pH}(\mathrm{n}=184)$, VFA ( $\mathrm{n}=192)$, and $\mathrm{NH}_{3} \mathrm{~N}(\mathrm{n}=192)$ measurements were analyzed with time as repeated measures using the first-order autoregressive covariance structure, which provided the best fit according to Sawa's Bayesian information criterion. The model included period, square, forage, NFC, hour, interactions for forage $\times$ $\mathrm{NFC}$, forage $\times$ hour, NFC $\times$ hour, and NFC $\times$ forage $\times$ hour as fixed effects; cow within square and forage $x$ $\mathrm{NFC} \times$ period $\times$ cow within square were random effects. Degrees of freedom were calculated using the Kenward-Roger option. Because of meter malfunction, $\mathrm{pH}$ measurements at $0330 \mathrm{~h}$ during period 4 were not made and, thus, were included in the statistical analysis as missing observations. Square $\times$ treatment interactions were originally evaluated but were removed from statistical models because they were not significant. Pearson correlation coefficients were determined between cow-period B-vitamin AS observations and some parameters. Ruminal $\mathrm{pH}, \mathrm{VFA}$, and $\mathrm{NH}_{3} \mathrm{~N}$ measures were averaged across time before correlation analysis. Main effects of forage, $\mathrm{NFC}$, the forage $\times \mathrm{NFC}$ interaction, and correlations were considered significant at $P<0.05$, and tendencies were considered at $P$ $<0.10$.

\section{RESULTS}

Diet ingredient composition, feedstuff nutrient composition, and orts-adjusted diet nutrient composition are presented in Tables 1, 2, and 3, respectively. Dietary NFC contents were similar to formulation targets. Dietary Co concentrations averaged $1.6 \mathrm{mg} / \mathrm{kg}$ of $\mathrm{DM}$ and were reflective of dietary proportions of the vitamin-mineral premix. Because Co concentrations were approximately 15 -fold higher than NRC (2001) guidelines of $0.11 \mathrm{mg} / \mathrm{kg}$ of DM, it is unlikely that variation among diets would influence $B_{12}$ synthesis.

Milk yields (data not shown in tables) were 32.7, $35.1,29.3$, and $32.1 \mathrm{~kg} / \mathrm{d}(\mathrm{SEM}=1.9)$ for cows fed the $35 \%$ forage $-30 \% \mathrm{NFC}, 35 \%$ forage $-40 \% \mathrm{NFC}, 60 \%$ forage- $30 \% \mathrm{NFC}$, and $60 \%$ forage- $30 \%$ NFC diets, respectively. Average milk yields were 3.2 and $2.6 \mathrm{~kg} / \mathrm{d}$ higher $(P<0.05)$ for cows fed the $35 \%$ forage $-40 \%$ NFC diets, respectively. Milk fat and true protein contents were 3.58 and $2.89,3.33$ and $2.88,3.80$ and 2.84 , and 3.62 and $2.83 \%$ for the $35 \%$ forage- $30 \%$ NFC, $35 \%$ forage $-40 \% \mathrm{NFC}, 60 \%$ forage- $30 \% \mathrm{NFC}$, and $60 \%$ for- age-30\% NFC diets, respectively $(\mathrm{SEM}=0.13$ and 0.05 , respectively). Increasing dietary forage increased $(P=0.003)$ milk fat and decreased $(P=0.04)$ milk true protein contents. Increasing dietary NFC decreased $(P=0.008)$ milk fat content. Milk fat yield and milk true protein content were higher $(P=0.02)$ and lower $(P=0.01)$, respectively, for cows in the earlier lactation square.

Daily intakes; ruminal digestibility; duodenal flow of DM, OM, NDF, and starch; daily intakes of NFC, nonstructural carbohydrates (NSC), and sugars; and duodenal $\mathrm{N}$ fractions are presented in Table 4. Increasing dietary forage from 35 to $60 \%$ decreased DM, OM, NDF, NFC, N, and sugar intakes as well as amounts of DM, OM, and NDF ruminally digested. Increasing dietary NFC from 30 to $40 \%$ increased NFC, NSC, and starch intakes and amount of starch ruminally digested; NDF and sugar intakes and amounts of NDF ruminally digested were decreased. Duodenal $\mathrm{NH}_{3} \mathrm{~N}$ and microbial $\mathrm{N}$ flow were lower and higher, respectively, for cows fed $40 \% \mathrm{NFC}$ diets. Increasing NFC had no effect on microbial $\mathrm{N}$ flow expressed as grams per kilogram of OM truly digested in the rumen (OMTD) for cows fed $35 \%$ forage diets, although it was increased for cows fed $60 \%$ forage diets (forage $x$ NFC; $P=0.04)$. Microbial N efficiency was higher $(P=$ 0.01 ) for cows in the earlier lactation square. Organic matter digestion and $\mathrm{N}$ fraction flow values in this experiment are within the ranges presented by Clark et al. (1992).

Effects of dietary forage and NFC content on ruminal $\mathrm{pH}, \mathrm{VFA}$, and $\mathrm{NH}_{3} \mathrm{~N}$ concentrations are presented in Table 5. Increasing dietary forage increased ruminal $\mathrm{pH}$ and ruminal acetate molar proportions and decreased total VFA concentrations and ruminal propionate and butyrate molar proportions. Increasing dietary NFC decreased ruminal acetate and increased ruminal propionate molar proportions. Increasing both dietary forage and NFC increased the sum of ruminal isobutyrate, isovalerate, and valerate molar proportions. Increasing NFC decreased ruminal $\mathrm{NH}_{3}$ $\mathrm{N}$ for cows fed $35 \%$ forage diets and increased ruminal $\mathrm{NH}_{3} \mathrm{~N}$ for cows fed $60 \%$ forage diets (forage $\times \mathrm{NFC}$; $P=0.04$ ).

Effects of dietary forage and NFC content on B-vitamin intake, flow, and AS are presented in Table 6. Daily B-vitamin AS was expressed as milligrams per kilogram of OM intake (OMI) per day to account for differences in feed intake and as milligrams per kilogram of OMTD for a measure of AS efficiency (Table 7). Differences observed in individual B-vitamin intakes coincided with differences in DMI and dietary B-vitamin concentrations. Except for PYR and biotin, duodenal flows of B-vitamins were higher than intake, indi- 
Table 6. B-vitamin intakes, ${ }^{1}$ duodenal flows, and apparent synthesis (AS) in lactating cows fed diets containing 35 or $60 \%$ forage and 30 or $40 \% \mathrm{NFC}^{2}$

\begin{tabular}{|c|c|c|c|c|c|c|c|c|}
\hline \multirow[b]{2}{*}{ Item } & \multicolumn{4}{|c|}{ Diet $^{3}$} & \multirow[b]{2}{*}{ SEM } & \multicolumn{3}{|c|}{ Effect } \\
\hline & $35-30$ & $35-40$ & $60-30$ & $60-40$ & & Forage & NFC & INT $^{4}$ \\
\hline & 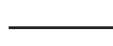 & m & & & & $\longrightarrow$ & $-P-$ & - \\
\hline \multicolumn{9}{|l|}{ Thiamin } \\
\hline Intake & 36.3 & 46.3 & 27.0 & 37.0 & 2.4 & $<0.001$ & $<0.001$ & 0.99 \\
\hline Duodenal flow & 96.9 & 94.2 & 70.7 & 86.9 & 6.9 & 0.005 & 0.21 & 0.09 \\
\hline AS & 60.6 & 47.9 & 43.8 & 50.0 & 5.3 & 0.13 & 0.38 & 0.06 \\
\hline \multicolumn{9}{|l|}{ Riboflavin } \\
\hline Intake & 98.2 & 96.1 & 111.4 & 117.2 & 7.1 & $<0.001$ & 0.65 & 0.33 \\
\hline Duodenal flow & 344.0 & 350.0 & 317.1 & 362.9 & 24.9 & 0.70 & 0.17 & 0.28 \\
\hline \multirow{2}{*}{\multicolumn{9}{|c|}{$\begin{array}{l}\text { AN } \\
N^{5}\end{array}$}} \\
\hline & & & & & & & & \\
\hline Intake & 620 & 489 & 462 & 363 & 31 & $<0.001$ & $<0.001$ & 0.38 \\
\hline Duodenal flow & 1209 & 1504 & 1016 & 1134 & 143 & 0.06 & 0.15 & 0.53 \\
\hline AS & 589 & 1015 & 555 & 771 & 133 & 0.31 & 0.03 & 0.44 \\
\hline \multicolumn{9}{|l|}{$\mathrm{NAM}^{5}$} \\
\hline Intake & 1399 & 838 & 727 & 221 & 56 & $<0.001$ & $<0.001$ & 0.46 \\
\hline Duodenal flow & 1256 & 1370 & 892 & 837 & 106 & $<0.001$ & 0.77 & 0.40 \\
\hline AS & $-143^{*}$ & 532 & $165^{*}$ & 615 & 99 & 0.06 & $<0.001$ & 0.27 \\
\hline \multicolumn{9}{|l|}{ Niacin } \\
\hline Intake & 2019 & 1327 & 1187 & 584 & 85 & $<0.001$ & $<0.001$ & 0.42 \\
\hline Duodenal flow & 2464 & 2874 & 1908 & 1970 & 221 & 0.003 & 0.27 & 0.42 \\
\hline $\mathrm{AS}$ & 446 & 1547 & 720 & 1386 & 196 & 0.78 & $<0.001$ & 0.28 \\
\hline \multicolumn{9}{|l|}{$\mathrm{PAL}^{5}$} \\
\hline Intake & 27.4 & 23.6 & 16.6 & 13.4 & 1.3 & $<0.001$ & $<0.001$ & 0.73 \\
\hline Duodenal flow & 30.8 & 36.7 & 25.6 & 27.3 & 2.3 & 0.001 & 0.03 & 0.82 \\
\hline AS & $3.4^{*}$ & 13.0 & 6.0 & 13.9 & 2.3 & 0.42 & $<0.001$ & 0.69 \\
\hline \multicolumn{9}{|l|}{$\mathrm{PAM}^{5}$} \\
\hline Intake & 8.6 & 14.9 & 7.7 & 13.5 & 0.8 & 0.03 & $<0.001$ & 0.62 \\
\hline Duodenal flow & 50.1 & 55.9 & 44.7 & 52.7 & 3.9 & 0.12 & 0.02 & 0.69 \\
\hline AS & 41.5 & 41.0 & 37.0 & 39.2 & 3.3 & 0.21 & 0.72 & 0.59 \\
\hline \multicolumn{9}{|l|}{ PYR $^{5}$} \\
\hline Intake & 30.9 & 30.3 & 35.1 & 36.0 & 2.3 & 0.002 & 0.91 & 0.60 \\
\hline Duodenal flow & 9.1 & 6.1 & 5.9 & 9.3 & 1.5 & 0.98 & 0.88 & 0.05 \\
\hline AS & -21.8 & -24.2 & -29.2 & -26.7 & 2.7 & 0.03 & 0.98 & 0.27 \\
\hline \multicolumn{9}{|l|}{$\mathrm{B}_{6}$} \\
\hline Intake & 66.9 & 68.9 & 59.4 & 62.9 & 4.2 & 0.01 & 0.29 & 0.77 \\
\hline Duodenal flow & 89.9 & 98.7 & 73.2 & 89.3 & 5.9 & 0.01 & 0.02 & 0.44 \\
\hline AS & 23.0 & 29.8 & 13.8 & 26.5 & 4.7 & 0.15 & 0.03 & 0.49 \\
\hline \multicolumn{9}{|l|}{ Biotin } \\
\hline Intake & 134.4 & 141.1 & 122.3 & 133.8 & 8.8 & 0.09 & 0.11 & 0.66 \\
\hline Duodenal flow & 119.5 & 130.4 & 106.8 & 131.2 & 8.7 & 0.37 & 0.01 & 0.31 \\
\hline AS & -14.9 & $-10.7^{*}$ & -15.5 & $-2.6^{*}$ & 6.3 & 0.56 & 0.19 & 0.50 \\
\hline \multicolumn{9}{|l|}{ Folates } \\
\hline Intake & 13.7 & 12.2 & 12.4 & 12.6 & 0.9 & 0.88 & 0.73 & 0.52 \\
\hline Duodenal flow & 28.9 & 32.4 & 25.4 & 29.0 & 2.4 & 0.04 & 0.04 & 0.98 \\
\hline AS & 16.3 & 20.2 & 13.0 & 16.4 & 2.0 & 0.04 & 0.04 & 0.86 \\
\hline \multicolumn{9}{|l|}{$\mathrm{B}_{12}$} \\
\hline Intake & 0.4 & 0.3 & 0.3 & 0.3 & 0.02 & 0.18 & 0.14 & 0.35 \\
\hline Duodenal flow & 102.6 & 79.0 & 79.7 & 60.4 & 5.9 & $<0.001$ & $<0.001$ & 0.53 \\
\hline AS & 102.2 & 78.6 & 78.4 & 60.1 & 5.9 & $<0.001$ & $<0.001$ & 0.54 \\
\hline
\end{tabular}

\footnotetext{
${ }^{1}$ Orts-corrected.

${ }^{2}$ Calculated by difference: $100-[\mathrm{CP}+(\mathrm{NDF}-\mathrm{NDICP})+$ fat + ash $]$. NDICP $=$ neutral detergent insoluble $\mathrm{CP}$.

${ }^{3} 35-30=35 \%$ forage $-30 \%$ NFC, $35-40=35 \%$ forage $-40 \%$ NFC, $60-30=60 \%$ forage $-30 \%$ NFC, and $60-$ $40=60 \%$ forage $-40 \%$ NFC (DM basis).

${ }^{4} \mathrm{INT}=$ Interaction of dietary forage and NFC content.

${ }^{5} \mathrm{NA}=$ Nicotinic acid, $\mathrm{NAM}=$ nicotinamide, $\mathrm{PAL}=$ pyridoxal, $\mathrm{PAM}=$ pyridoxamine , and $\mathrm{PYR}=$ pyridoxine.

*Value not different from zero $(P>0.05)$.
}

cating ruminal production. Increasing NFC tended (forage $\times \mathrm{NFC} ; P=0.06$ ) to decrease daily thiamin AS (expressed as $\mathrm{mg}$ or $\mathrm{mg} / \mathrm{kg}$ of OMTD) for cows fed $35 \%$ forage diets; the opposite effect occurred for cows fed $60 \%$ forage diets. Daily niacin AS ( $\mathrm{mg}, \mathrm{mg} / \mathrm{kg}$ of OMI, or $\mathrm{mg} / \mathrm{kg}$ of OMTD) was higher for cows fed $40 \% \mathrm{NFC}$ 
Table 7. Daily B-vitamin apparent synthesis (AS) [expressed as $\mathrm{mg} / \mathrm{kg}$ of OM intake (OMI) and $\mathrm{mg} / \mathrm{kg}$ of OM truly digested ruminally (OMTD)] in lactating cows fed diets containing either 35 or $60 \%$ forage and 30 or $40 \% \mathrm{NFC}^{1}$

\begin{tabular}{|c|c|c|c|c|c|c|c|c|}
\hline \multirow[b]{2}{*}{ Item } & \multicolumn{4}{|c|}{ Diet $^{2}$} & \multirow[b]{2}{*}{ SEM } & \multicolumn{3}{|c|}{ Effect } \\
\hline & $35-30$ & $35-40$ & $60-30$ & $60-40$ & & $\mathrm{~F}$ & $\mathrm{NFC}$ & $\mathrm{INT}^{3}$ \\
\hline & & & & & & & $-P$ & 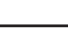 \\
\hline \multicolumn{8}{|l|}{ Thiamin AS } & 0.08 \\
\hline $\mathrm{mg} / \mathrm{kg}$ of OMTD & 5.7 & 4.1 & 4.7 & 5.2 & 0.5 & 0.95 & 0.32 & 0.06 \\
\hline \multicolumn{9}{|l|}{ Riboflavin AS } \\
\hline $\mathrm{mg} / \mathrm{kg}$ of $\mathrm{OMI}$ & 12.6 & 12.4 & 12.5 & 13.6 & 0.8 & 0.45 & 0.58 & 0.39 \\
\hline $\mathrm{mg} / \mathrm{kg}$ of OMTD & 22.8 & 21.9 & 22.7 & 27.0 & 2.2 & 0.26 & 0.45 & 0.24 \\
\hline \multicolumn{9}{|l|}{ Niacin AS } \\
\hline $\mathrm{mg} / \mathrm{kg}$ of $\mathrm{OMI}$ & 25.2 & 73.2 & 43.9 & 78.7 & 10.2 & 0.25 & $<0.001$ & 0.53 \\
\hline $\mathrm{mg} / \mathrm{kg}$ of OMTD & 47.2 & 130.1 & 81.5 & 162.2 & 22.2 & 0.15 & 0.002 & 0.96 \\
\hline \multicolumn{9}{|l|}{$\mathrm{B}_{6} \mathrm{AS}$} \\
\hline $\mathrm{mg} / \mathrm{kg}$ of $\mathrm{OMI}$ & 1.2 & 1.5 & 0.8 & 1.5 & 0.3 & 0.42 & 0.05 & 0.33 \\
\hline $\mathrm{mg} / \mathrm{kg}$ of OMTD & 2.3 & 2.5 & 1.5 & 2.9 & 0.5 & 0.66 & 0.09 & 0.25 \\
\hline \multicolumn{9}{|l|}{ Folates AS } \\
\hline $\mathrm{mg} / \mathrm{kg}$ of $\mathrm{OMI}$ & 0.8 & 1.0 & 0.8 & 0.9 & 0.1 & 0.51 & 0.16 & 0.93 \\
\hline $\mathrm{mg} / \mathrm{kg}$ of OMTD & 1.5 & 1.7 & 1.4 & 1.8 & 0.2 & 0.96 & 0.19 & 0.64 \\
\hline \multicolumn{9}{|l|}{$\mathrm{B}_{12} \mathrm{AS}$} \\
\hline $\mathrm{mg} / \mathrm{kg}$ of $\mathrm{OMI}$ & 5.3 & 3.8 & 4.8 & 3.3 & 0.2 & 0.02 & $<0.001$ & 0.89 \\
\hline $\mathrm{mg} / \mathrm{kg}$ of OMTD & 9.4 & 6.7 & 8.6 & 6.4 & 0.6 & 0.33 & $<0.001$ & 0.70 \\
\hline
\end{tabular}

\footnotetext{
${ }^{1}$ Calculated by difference: $100-[\mathrm{CP}+(\mathrm{NDF}-\mathrm{NDICP})+$ fat + ash $]$ NDICP $=$ neutral detergent insoluble CP.

${ }^{2} 35-30=35 \%$ forage $-30 \%$ NFC, $35-40=35 \%$ forage $-40 \%$ NFC, $60-30=60 \%$ forage $-30 \%$ NFC, and $60-$ $40=60 \%$ forage $-40 \%$ NFC (DM basis).

${ }^{3} \mathrm{INT}=$ Interaction of dietary forage and NFC content.
}

diets, as were amounts of NA and NAM. Duodenal flow of PAL and PYR were higher $(P<0.05)$ for cows in the later lactation square. Daily vitamin $\mathrm{B}_{6} \mathrm{AS}(\mathrm{mg}$ or $\mathrm{mg} / \mathrm{kg}$ of OMTD) was higher for cows fed $40 \%$ NFC diets. This increase in $\mathrm{B}_{6} \mathrm{AS}(\mathrm{mg} / \mathrm{d})$ was due to an increase in PAL AS as there was no effect of dietary NFC content on PAM or PYR AS. Ruminal PYR disappearance (negative AS) was greater for the $60 \%$ forage diets. Vitamin $\mathrm{B}_{6}$ and PAL AS were higher $(P<0.05)$ for cows in the later lactation square. Folate AS (mg/ d) was lower and higher for cows fed $60 \%$ forage and $40 \%$ NFC diets, respectively; daily $\mathrm{B}_{12} \mathrm{AS}(\mathrm{mg}, \mathrm{mg} / \mathrm{kg}$ of OMI, mg/kg of OMTD) was lower for cows fed $40 \%$ NFC diets. Similarly, increasing dietary forage decreased daily $\mathrm{B}_{12} \mathrm{AS}$ ( $\mathrm{mg}$ and $\mathrm{mg} / \mathrm{kg}$ of $\mathrm{OMI}$ ).

Pearson correlation coefficients between B-vitamin AS and nutrient intakes, amounts of nutrients ruminally digested, and duodenal flow of microbial $\mathrm{N}$ are presented in Table 8.

\section{DISCUSSION}

Dietary forage and NFC effects on AS could be due to changes in populations or functions of ruminal microbial species, their interrelationships, and subsequent effects on microbial B-vitamin metabolism. Wolin et al. (1997) suggested that B-vitamin "cross- feeding" occurs between ruminal bacteria; B-vitamins that are produced by one species may be required by another. To our knowledge, no research has been conducted investigating the relationship between changes in ruminal microbial populations and B-vitamin synthesis and (or) degradation. Although ruminal degradation of supplemental B-vitamins clearly occurs (Zinn et al., 1987; Santschi et al., 2005a), information is lacking with regard to how degraded B-vitamins are used by rumen microbes.

Studies (Hollis et al., 1954; Hayes et al., 1966; Girard et al., 1994) have reported that altering dietary ingredients affects ruminal B-vitamin concentrations. Ruminal concentrations, however, may not represent total microbial B-vitamin synthesis because rumen fill and digesta passage rates-particularly where large differences in dietary forage content exist-may be influenced by diet composition. Estimating B-vitamin AS as the difference between amounts flowing to the duodenum and dietary intake ignores microbial destruction, possible ruminal absorption, and the potential contribution of feed-derived B-vitamins available for intestinal absorption. To our knowledge, no data measuring ruminal destruction or bioavailability of feed-derived B-vitamins are available.

Although limited, data do suggest that there is no appreciable ruminal absorption of B-vitamins in fed ruminants. Rérat et al. (1958a) observed little ruminal 
Table 8. Pearson correlation coefficients between B-vitamin apparent synthesis (AS) and dietary and digestive parameters

\begin{tabular}{|c|c|c|c|c|c|c|}
\hline \multirow[b]{2}{*}{ Item } & \multicolumn{6}{|c|}{ B-vitamin AS } \\
\hline & Thiamin & Riboflavin & Niacin & $\mathrm{B}_{6}$ & Folates & $\mathrm{B}_{12}$ \\
\hline \multicolumn{7}{|l|}{ Intake, $\mathrm{kg} / \mathrm{d}$} \\
\hline DM & $0.51 * * *$ & $0.72 * * * *$ & 0.23 & 0.12 & $0.63^{* * * * *}$ & $0.61^{* * * * *}$ \\
\hline $\mathrm{OM}$ & $0.51 * * *$ & $0.71 * * * *$ & 0.23 & 0.12 & $0.63 * * * *$ & $0.61^{* * * *}$ \\
\hline $\mathrm{NDF}$ & $0.50^{* * *}$ & $0.47 * * *$ & -0.23 & -0.07 & $0.31^{*}$ & $0.88^{* * * * *}$ \\
\hline NFC & $0.32 *$ & $0.65^{* * * *}$ & $0.55^{* * * * *}$ & 0.26 & $0.67 * * * *$ & 0.16 \\
\hline NSC & 0.16 & $0.51^{* * *}$ & $0.65^{* * * * *}$ & 0.29 & $0.57 * * * *$ & -0.15 \\
\hline Starch & 0.06 & $0.41 * *$ & $0.67 * * * *$ & 0.28 & $0.48^{* * *}$ & $-0.31^{*}$ \\
\hline Sugars & $0.59^{* * * * *}$ & $0.62 * * * *$ & -0.01 & 0.06 & $0.53^{* * *}$ & $0.82^{* * * *}$ \\
\hline \multicolumn{7}{|l|}{ Dietary content, \% of DM } \\
\hline $\mathrm{NDF}$ & 0.14 & -0.19 & $-0.61 * * * *$ & -0.26 & -0.28 & $0.57 * * * *$ \\
\hline $\mathrm{NFC}^{1}$ & -0.10 & 0.23 & $0.62 * * * *$ & $0.30^{*}$ & $0.34 *$ & $-0.49 * * *$ \\
\hline $\mathrm{NSC}^{2}$ & -0.13 & 0.20 & $0.62 * * * *$ & 0.27 & $0.29 *$ & $-0.55^{* * * * *}$ \\
\hline Starch & -0.14 & 0.18 & $0.61^{* * * *}$ & 0.26 & 0.27 & $-0.57 * * * *$ \\
\hline Sugars & 0.28 & -0.04 & $-0.50 * * *$ & -0.11 & -0.05 & $0.69^{* * * *}$ \\
\hline \multicolumn{7}{|l|}{ Ruminally digested, $\mathrm{kg} / \mathrm{d}$} \\
\hline $\mathrm{DM}^{3}$ & $0.37 * *$ & $0.51^{* * *}$ & 0.10 & 0.11 & $0.52 * * *$ & $0.52^{* * *}$ \\
\hline $\mathrm{OM}^{3}$ & $0.40 * *$ & $0.49 * * *$ & 0.04 & 0.14 & $0.50 * * *$ & $0.54 * * * *$ \\
\hline $\mathrm{NDF}$ & 0.19 & 0.13 & $-0.32^{*}$ & -0.15 & 0.05 & $0.67 * * * *$ \\
\hline Starch & 0.13 & $0.46^{* * *}$ & $0.62^{* * * * *}$ & $0.29 *$ & $0.54^{* * * *}$ & -0.21 \\
\hline Microbial N flow, g/d & $0.65^{* * * * *}$ & $0.79 * * * *$ & $0.38 * *$ & 0.14 & $0.77 * * * *$ & $0.44^{* * *}$ \\
\hline \multicolumn{7}{|l|}{ Ruminal measures } \\
\hline VFA & & & & & & \\
\hline Total, $\mathrm{m} M$ & $0.51 * * *$ & $0.46^{* * * *}$ & 0.13 & 0.23 & $0.43 * * *$ & $0.54 * * * *$ \\
\hline Acetate, $\mathrm{mol} / 100 \mathrm{~mol}$ & $-0.41^{* *}$ & $-0.42^{* *}$ & $-0.29 *$ & $-0.35 * *$ & $-0.49 * * *$ & -0.18 \\
\hline Propionate, $\mathrm{mol} / 100 \mathrm{~mol}$ & 0.20 & $0.32 *$ & $0.33^{*}$ & $0.40^{* *}$ & $0.57 * * * *$ & 0.18 \\
\hline Butyrate, mol/100 mol & $0.39 * *$ & $0.31 *$ & 0.11 & 0.16 & 0.21 & 0.24 \\
\hline $\mathrm{pH}$ & $-0.42^{* *}$ & $-0.39 * *$ & 0.04 & -0.21 & $-0.39^{* *}$ & $-0.67 * * * *$ \\
\hline $\mathrm{NH}_{3} \mathrm{~N}, \mathrm{mg} / \mathrm{dL}$ & $0.35^{* *}$ & 0.23 & -0.18 & -0.01 & 0.15 & 0.17 \\
\hline
\end{tabular}

${ }^{1} \mathrm{NFC}$ calculated by difference: $100-(\mathrm{CP}+(\mathrm{NDF}-\mathrm{NDICP})+$ fat + ash $) . \mathrm{NDICP}=$ Neutral detergent insoluble $\mathrm{CP}$.

${ }^{2} \mathrm{NSC}=$ Nonstructural carbohydrates.

${ }^{3}$ Digestibility corrected for duodenal flow of microbial DM and OM.

$* P<0.10, * * P<0.05, * * * P<0.01$, and $* * * * P<0.001$.

B-vitamin absorption in fed sheep but did observe absorption when B-vitamins were infused into an evacuated rumen (Rérat et al., 1958b). During a 1-h period, approximately $31 \%$ of a 3.2-g NAM dose was absorbed from evacuated rumens, yet NA was not absorbed (Erickson et al., 1991). Harmeyer and Kollenkirchen (1989) suggested that NAM is instantly converted to NA in the rumen. Girard et al. (2001) calculated that only 0.015 and $4 \times 10^{-6} \%$ of 2.6 - and 7.8-g doses of folic acid and $\mathrm{B}_{12}$, respectively, were ruminally absorbed within $1 \mathrm{~h}$ of dosing. Hoeller et al. (1977) showed in vitro that the rumen wall is largely thiamin-impermeable. Santschi et al. (2005b) indicated that B-vitamin concentrations were 10- to 5,000-fold higher in bacteria than in particle-free supernatant. Those results are in accordance with Rérat et al. (1959), who reported that in the rumen, B-vitamins are primarily sequestered within bacteria, which would reduce the possibility of ruminal absorption. Because ruminal Bvitamin absorption appears negligible, calculations of AS should provide a reasonable estimate of B-vitamin supply to the animal by the ruminal microbial population.

Zinn et al. (1987) reported linear increases in duodenal flow of thiamin, niacin, vitamin $\mathrm{B}_{6}$, and $\mathrm{B}_{12}$ when intakes of grain-fed steers increased incrementally from 1.2 to $2.2 \%$ of $\mathrm{BW}$. When AS was estimated from Zinn et al. (1987), amounts of B-vitamins ruminally synthesized also appeared to increase with increasing feed intake.

When averaged across diets, thiamin AS was 50.6 $\mathrm{mg} / \mathrm{d}$, which is similar to the values of $51.7 \mathrm{mg} / \mathrm{d}$ reported by Breves et al. (1981) and greater than the $26.1 \mathrm{mg} / \mathrm{d}$ reported by Santschi et al. (2005a) in lactating dairy cows. Similarly, Steinberg and Kaufmann (1977) reported that thiamin AS ranged from 23 to 50 $\mathrm{mg} / \mathrm{d}$ with a mean of $32 \mathrm{mg} / \mathrm{d}$. Using steers, Miller et al. (1986) reported a net thiamin loss, which they hypothesized was due to destruction by thiaminase enzymes. Daily thiamin AS was $4.0 \mathrm{mg} / \mathrm{kg}$ of OMI calculated from Breves et al. (1981) vs. an average of 2.7 $\mathrm{mg} / \mathrm{kg}$ of OMI in our study. Using raw cow-period data 
provided by Breves et al. (1981), thiamin AS was correlated $(\mathrm{r}=0.76, P<0.001)$ with duodenal microbial $\mathrm{N}$ flow, which was similar to our observed correlation between these parameters.

Increasing dietary forage increased riboflavin intake in our study and that of Miller et al. (1986). However, riboflavin flow and AS were not different between high- and low-forage fed steers (Miller et al., 1986). Santschi et al. (2005a) reported that riboflavin AS averaged $267 \pm 17 \mathrm{mg} / \mathrm{d}$, similar to our across-diet average of $238 \mathrm{mg} / \mathrm{d}$. Calculated daily riboflavin AS ranged from 0.4 (Zinn et al., 1987) to $9.8 \mathrm{mg} / \mathrm{kg}$ of OMI (Miller et al., 1986), which are lower than our across-diet average of $12.8 \mathrm{mg} / \mathrm{kg}$ of OMI. Positive correlations for thiamin and riboflavin AS with nutrient intake (but not nutrient content), ruminal DM and OM digestibility, and duodenal microbial $\mathrm{N}$ flow, and the correlations with ruminal VFA parameters suggest that AS of these vitamins is increased as dietary intake, ruminal digestibility, and microbial $\mathrm{N}$ production increase.

Niacin AS was 4- to 62-fold greater than the other B-vitamins, excluding biotin. Considerably lower AS values for NAM than NA may support the hypothesis of Harmeyer and Kollenkirchen (1989) that NAM is hydrolyzed to NA. Similarly, a portion of NAM could be converted to NA during analysis with extraction procedures involving acids (Ndaw et al., 2002) such as those used in the present experiment. In our study, increasing dietary NFC content increased niacin AS by $884 \mathrm{mg} / \mathrm{d}$, or about 2.5 -fold, in contrast to Miller et al. (1986) where no difference $(P>0.20)$ was observed between high and low-forage diets. In our study, niacin AS was positively correlated with NFC, NSC, and starch intakes, as well as dietary starch content and amounts ruminally digested. In contrast, niacin AS was negatively correlated with amounts of NDF digested ruminally, dietary NDF content, and ruminal molar percentage of acetate but positively correlated with ruminal molar percentage of propionate. Santschi et al. (2005a) reported that niacin AS was $2213 \pm 224$ $\mathrm{mg} / \mathrm{d}$ in lactating cows fed diets containing $58 \%$ forage, $28 \% \mathrm{NDF}$, and $47 \% \mathrm{NFC}$ with average DMI of 19.8 $\mathrm{kg} / \mathrm{d}$. The niacin AS value reported by Santschi et al. (2005a) is approximately $830 \mathrm{mg} / \mathrm{d}$ higher that that for our $60 \%$ forage $-40 \%$ NFC diet, which may be partially due to dietary differences between the studies.

As observed in our study, Zinn et al. (1987) reported positive $\mathrm{B}_{6}$ AS, whereas Santschi et al. (2005a) reported negative AS $(-14 \pm 7 \mathrm{mg} / \mathrm{d})$. In our experiment and that of Santschi et al. (2005a), PYR AS values were negative, yet PAM and PAL AS were positive. Pyridoxine intakes were greater than PAL, which in turn were greater than PAM intakes, yet AS values of these vitamers were reversed. This suggests that there is ruminal metabolism of PYR or microbial conversion of PYR to another $B_{6}$ vitamer, conceivably PAM. This hypothesis is further supported by the observation that PYR represented $>60 \%$ of total vitamin $\mathrm{B}_{6}$ in diets, but accounted for $\leq 5 \%$ in ruminal bacterial fractions (Santschi et al., 2005b). When averaged across diets, daily $\mathrm{B}_{6}$ AS was $1.3 \mathrm{mg} / \mathrm{kg}$ of OMI and lower than the $4.6 \mathrm{mg} / \mathrm{kg}$ of OMI calculated from Zinn et al. (1987). Increased $\mathrm{B}_{6}$ AS with increasing dietary NFC content combined with positive correlations with kilograms of starch digested, dietary NFC content, and positive and negative correlations with ruminal molar percentages of propionate and acetate, respectively, suggests that $\mathrm{B}_{6}$ synthesis may be closely linked to NFC digestion.

In our study and that of Santschi et al. (2005a), biotin AS values were negative and averaged -10.9 and $-1.4 \mathrm{mg} / \mathrm{d}$, respectively. Miller et al. (1986) reported that ruminal biotin synthesis was $<1 \mathrm{mg} / \mathrm{d}$ in steers fed either high-corn grain (88\% dietary DM) or high-alfalfa meal (70\% dietary DM) diets. Calculated biotin AS was positive in the study of Zinn et al. (1987). In vitro data (Abel et al., 2001) indicate that ruminal microflora synthesize more (or degrade less) biotin as hay replaces barley grain. Utilizing healthy hay- and grain-fed fistulated sheep, Duncan et al. (1999) isolated Pseudomonas aeruginosa from ruminal digesta, a bacterial genus that has been shown to degrade biotin (Brady et al., 1965). Positive biotin AS values observed by Miller et al. (1986) and Zinn et al. (1987) could have occurred as the microbiological assays used by these researchers might not have completely accounted for biocytin (biotin bound to lysine) in feed and duodenal samples. The link between lysine and biotin is cleaved only by biotinidase (McMahon, 2002), an enzyme present in the pancreas, intestinal brushborder cells, and some bacterial species. If the aforementioned researchers did not include exogenous enzyme in their assays, diet-derived biotin might have been underestimated. Without treatment with pancreatic extract, biocytin was not detected with the assay used in the present experiment, but the rate of conversion of biocytin to biotin following the enzymatic treatment was $92 \%$. When duodenal and various feed samples were analyzed with and without pancreatic extract, we (unpublished observations) found that approximately $93 \%$ of total biotin was present as biocytin. However, it is possible that the assay used in the present experiment also detected inactive metabolites such as biotin sulfoxide or bisnorbiotin, overestimating total biotin concentrations in feed and duodenal digesta.

Daily folate AS averaged $16.5 \mathrm{mg}$ and was similar to the $21 \mathrm{mg}$ reported by Santschi et al. (2005a). However, 
folate AS calculated from Zinn et al. (1987) was negative. This discrepancy could be partially due to absorption of folates prior to the duodenal cannula (Santschi et al., 2005a), leading to underestimation of folate AS. However, the extent of absorption from the proximal duodenum has not been precisely quantified. Girard et al. (1994) observed numerically lower ruminal folate concentrations in steers fed high-forage diets $(70 \%$ timothy hay, DM basis) than those fed low-forage (30\% timothy hay, DM basis) diets, although folic acid intakes were higher for the high-forage diets. However, ruminal concentrations may not reflect the amount of folates escaping from the rumen. Although increasing dietary forage and NFC content increased duodenal flow and AS of folates, these effects were not significant when AS was reported per kilogram of OMI. Positive correlations with microbial $\mathrm{N}$ flow and intake and ruminal digestion of all measured nutrients except NDF and correlations with ruminal VFA parameters suggest that folates AS is increased when overall nutrient intake and ruminal digestibility are improved.

Daily $\mathrm{B}_{12}$ AS averaged $79.8 \mathrm{mg}$, which is similar to the 73-mg value of Santschi et al. (2005a). Decreased AS of $\mathrm{B}_{12}$ with increased dietary corn grain content was observed in sheep (Sutton and Elliot, 1972). In the present experiment, increasing both dietary forage and NFC-whether expressed as milligrams per day or milligrams per kilogram of OMI per day-reduced $\mathrm{B}_{12} \mathrm{AS}$. Vitamin $\mathrm{B}_{12} \mathrm{AS}$ was highest for the $35 \%$ forage diets, on which cows consumed the greatest quantity of sugars. Selenomonas bacteria have been shown to synthesize appreciable amounts of $\mathrm{B}_{12}$ (Dryden et al., 1962; Anderson et al., 2001) and use sugars as fermentative substrates (Stewart and Bryant, 1988). Though purely supposal, the nutrient content of the $35 \%$ forage diets might have fostered proliferation of these bacteria. Vitamin $\mathrm{B}_{12} \mathrm{AS}$ was positively correlated with measurements of sugars and NDF and was negatively correlated with dietary NFC, NSC, and starch content.

The NRC (2001) provides estimates of apparent ruminal B-vitamin synthesis in lactating dairy cows based on steer data of Miller et al. (1986) and Zinn et al. (1987). To investigate the validity of this approach, we adapted those data to AS measurements from our experiment by expressing the NRC (2001) estimates on the basis of milligrams per kilogram of DMI per day (NRC assumed DMI of $22.9 \mathrm{~kg} / \mathrm{d}$ ) and multiplying by our across-diet average DMI measurements. These adjusted B-vitamin AS means are compared with our measured mean, minimum, and maximum AS values in Table 9. Relative to our measured AS values, the NRC (2001) closely estimated riboflavin AS; overestimated thiamin, $\mathrm{B}_{6}$, and biotin AS; and underestimated folic acid AS. The NRC (2001) estimates of niacin and
Table 9. Comparison of NRC (2001) adapted and measured B-vitamin apparent synthesis (AS)

\begin{tabular}{|c|c|c|c|c|}
\hline & \multicolumn{4}{|c|}{ B-vitamin AS } \\
\hline & \multirow{2}{*}{$\frac{\mathrm{NRC}^{1}}{\text { Mean }}$} & \multicolumn{3}{|c|}{ Measured } \\
\hline & & Mean & Minimum & Maximum \\
\hline Thiamin & 127 & 51 & 44 & 61 \\
\hline Riboflavin & 232 & 238 & 206 & 254 \\
\hline Niacin & 1603 & 1025 & 446 & 1547 \\
\hline $\mathrm{B}_{6}$ & 85 & 23 & 14 & 30 \\
\hline Biotin & 12 & -11 & -16 & -3 \\
\hline Folates & 6.2 & 16 & 13 & 20 \\
\hline $\mathrm{B}_{12}$ & 62 & 80 & 60 & 102 \\
\hline
\end{tabular}

${ }^{1} \mathrm{NRC}(2001)$ ruminal synthesis ( $\mathrm{mg} / \mathrm{kg}$ of DMI per $\mathrm{d}$ ) adjusted to average DMI measured in the current study.

$\mathrm{B}_{12}$ AS were similar to measured maximum and minimum values, respectively. With regard to ranking Bvitamins by amounts synthesized, the 2 approaches are similar; niacin and riboflavin syntheses were highest followed by thiamin, $\mathrm{B}_{6}$, and $\mathrm{B}_{12}$. The lowest values were for folic acid and biotin. Because of the variation in relationships between individual B-vitamin AS and nutrient intakes, nutrient digestibility and microbial $\mathrm{N}$ flow, and forage and NFC effects on AS, future prediction equations estimating B-vitamin AS will likely need to be multifactorial and B-vitamin specific.

\section{CONCLUSIONS}

When averaged across diets, AS of individual B-vitamins as a percentage of B-vitamin intake was thiamin, 142; riboflavin, 228; total niacin, 120 ; total $\mathrm{B}_{6}, 39$; folic acid, 137; and $\mathrm{B}_{12}, 24,276$, clearly exemplifying the importance of ruminal synthesis for most B-vitamins. Increasing dietary forage and NFC contents influenced B-vitamin intakes, duodenal flow, and AS. When expressed as milligrams per day, B-vitamin duodenal flow and AS were influenced more frequently by dietary NFC content than by dietary forage content. When adjusted for OMI, only $\mathrm{B}_{12} \mathrm{AS}$ was influenced by dietary forage content, whereas niacin, $\mathrm{B}_{6}$, and $\mathrm{B}_{12}$ were influenced by NFC content. Thiamin, riboflavin, and folic acid AS appear to be increased when overall dietary intake and digestibility and microbial $\mathrm{N}$ production increase; $\mathrm{B}_{6}$ and niacin AS are enhanced with increased dietary NFC content. Negative AS values for biotin suggest minimal ruminal synthesis and/or appreciable ruminal degradation. Vitamin $\mathrm{B}_{12} \mathrm{AS}$ was highest for $35 \%$ forage-30\% NFC diets and was increased with increasing dietary sugars. Additional research investigating dietary effects on duodenal Bvitamin flows and ruminal AS, coupled with lactating cow requirement and intestinal B-vitamin absorption 
research, will allow for determination of dietary Bvitamin supplementation strategies.

\section{ACKNOWLEDGMENTS}

Appreciation is extended to the farm crews at the University of New Hampshire Dairy Teaching and Research Center for care of the cows; to Ryan Ordway, Sarah Boucher, and Kathryn Cowles for assistance in sample collection; to Sandy Bertics for VFA analysis; to Chrystiane Plante, Véronique Roy, and Débora Sanstchi for B-vitamin analysis; to Peter Crump for statistical advice; and to Katherine Knowlton for the duodenal cannulae.

\section{REFERENCES}

Abel, H. J., I. Immig, C. Da Costa Gomez, and W. Steinberg. 2001. Research note: Efect of increasing dietary concentrate levels on microbial biotin metabolism in the artificial rumen simulation system (RUSITEC). Arch. Anim. Nutr. 55:371-376.

Anderson, P. J., B. Entsch, and D. B. McKay. 2001. A gene, cobA + hemD, from Selenomonas ruminantium encodes a bifunctional enzyme involved in the sythesis of vitamin B12. Gene 281:63-70.

Association of Official Analytical Chemists. 1990. Official Methods of Analysis. Vol. I. 15th ed. Assoc. Off. Anal. Chem., Arlington, VA.

Brady, R. N., L. F. Li, D. B. McCormick, and L. D. Wright. 1965. Bacterial and enzymatic degradation of biotin. Biochem. Biophys. Res. Commun. 19:777-782.

Breves, G., M. Brandt, H. Hoeller, and K. Rohr. 1981. Flow of thiamin to the duodenum in dairy cows fed different rations. J. Agric. Sci. (Camb.) 96:587-591.

Clark, J. H., T. H. Klusmeyer, and M. R. Cameron. 1992. Microbial protein synthesis and flows of nitrogen fractions to the duodenum of dairy cows. J. Dairy Sci. 75:2304-2323.

Conrad, H. R., and J. W. Hibbs. 1954. A high roughage system for raising calves based on early rumen development. IV. Synthesis of thiamin and riboflavin in the rumen as influenced by the ratio of hay to grain fed and initiation of dry feed consumption. J. Dairy Sci. 37:512-522.

Dryden, L. P., A. M. Hartman, M. P. Bryant, I. M. Robinson, and L. A. Moore. 1962. Production of vitamin B12 and vitamin B12 analogues by pure cultures of ruminal bacteria. Nature 195:201-202.

Duncan, S. H., C. J. Doherty, J. R. W. Govan, S. Neogrady, P. Glafi, and C. S. Stewart. 1999. Characteristics of sheep-rumen isolates of Pseudomonas aeruginosa inhibitory to the growth of Escherichia coli O157. FEMS Microbiol. Lett. 180:305-310.

Erickson, P. S., M. R. Murphy, C. S. McSweeney, and A. M. Trusk. 1991. Niacin absorption from the rumen. J. Dairy Sci. 74:3492-3495.

French, P. D. 2004. Nicotinic acid supplemented at a therapeutic level minimizes prepartum feed intake depression in dairy cows. J. Dairy Sci. 87(Suppl. 1):345. (Abstr.)

Girard, C. L., J. Chiquette, and J. J. Matte. 1994. Concentrations of folates in ruminal content of steers: Responses to dietary supplement of folic acid in relation with the nature of the diet. J. Anim. Sci. 72:1023-1028.

Girard, C. L., H. Lapierre, A. Desrochers, C. Benchaar, J. J. Matte, and D. Rémond. 2001. Net flux of folates and vitamin B12 through the gastrointestinal tract and the liver of lactating dairy cows. Br. J. Nutr. 86:707-715.

Girard, C. L., H. Lapierre, J. J. Mattee, and G. E. Lobley. 2005. Effects of dietary supplements of folic acid and rumen-protected methionine on lactational performance and folate metabolism of dairy cows. J. Dairy Sci. 88:660-670.
Girard, C. L., and J. J. Matte. 1998. Dietary supplements of folic acid during lactation: Effects on the performance of dairy cows. J. Dairy Sci. 81:1412-1419.

Hall, M. B., W. H. Hoover, J. P. Jennings, and T. K. Miller Webster. 1999. A method for partitioning neutral detergent soluble carbohydrates. J. Sci. Food Agric. 79:2079-2086.

Harmeyer, J., and U. Kollenkirchen. 1989. Thiamin and niacin in ruminant nutrition. Nutr. Res. Rev. 2:201-225.

Hayes, B. W., G. E. Mitchell, Jr., C. O. Little, and N. W. Bradley. 1966. Concentrations of B-vitamins in ruminal fluid of steers fed different levels and physical forms of hay and grain. J. Anim. Sci. 25:539-542.

Hoeller, H., M. Fecke, and K. Schaller. 1977. Permeability to thiamin of the sheep rumen wall in vitro. J. Anim. Sci. 44:158-161.

Hollis, L., C. F. Chappel, R. MacVicar, and C. K. Whitehair. 1954. Effect of ration on vitamin synthesis in rumen of sheep. J. Anim. Sci. 13:732-738.

Majee, D. N., E. C. Schwab, S. J. Bertics, W. M. Seymour, and R. D. Shaver. 2003. Lactation performance by dairy cows fed supplemental biotin and a B-vitamin blend. J. Dairy Sci. 86:2106-2112.

McMahon, R. J. 2002. Biotin in metabolism and molecular biology. Annu. Rev. Nutr. 22:221-239.

Miller, B. L., J. C. Meiske, and R. D. Goodrich. 1986. Effects of grain and concentrate level on B-vitamin production and absorption in steers. J. Anim. Sci. 62:473-483.

National Research Council. 2001. Nutrient Requirements of Dairy Cattle. 7th rev. ed. Natl. Acad. Press, Washington, DC.

Ndaw, S., M. Bergaentzlé, D. Adoué-Werner, and C. Hasselmann. 2002. Enzymatic extraction procedure for the liquid chromatographic determination of niacin in foodstuffs. Food Chem. 78:129-134

Putnam, D. E., C. G. Schwab, M. T. Socha, N. L. Whitehouse, N. A. Kierstead, and B. D. Garthwaite. 1997. Effect of yeast culture in diets of early lactation dairy cows on ruminal fermentation and passage of nitrogen fractions and amino acids to the small intestine. J. Dairy Sci. 80:374-384.

Rérat, A., O. Champigny, and R. Jacquot. 1959. Modalités de l'absorption vitaminique chez les Ruminants: Forme et disponibilité des vitamines B du bol alimentaire aux différents niveaux digestifs. Académie des Sciences de Paris. Comptes rendus. 249:1274-1276.

Rérat, A., H. LeBars, and J. Molle. 1958a. Utilisation d'une méthode de perfusion pour la mise en évidence de l'absorption des vitamines B chez le Mouton normalement alimenté. Académie des sciences de Paris. Comptes rendus. 246:1920-1922.

Rérat, A., J. Molle, and H. Le Bars. 1958b. Mise en évidence chez le Mouton de la perméabilité du rumen aux vitamines B et conditions de leur absorption à ce niveau. Académie des Sciences de Paris. Comptes rendus. 246:2051-2054.

Rosendo, O., C. R. Staples, L. R. McDowell, R. McMahon, L. Badinga, F. G. Martin, J. F. Shearer, W. M. Seymour, and N. S. Wilkinson. 2004. Effects of biotin supplementation on peripartum performance and metabolites of Holstein cows. J. Dairy Sci. $87: 2535-2545$

Santschi, D. E., R. Berthiaume, J. J. Matte, A. F. Mustafa, and C. L. Girard. 2005a. Fate of supplementary B-vitamins in the gastrointestinal tract of dairy cows. J. Dairy Sci. 88:2043-2054.

Santschi, D. E., J. Chiquette, R. Berthiaume, R. Martineau, J. J. Matte, A. F. Mustafa, and C. L. Girard. 2005b. Effect of the forage to concentrate ratio on B-vitamin concentrations in different ruminal fractions of dairy cows. Can. J. Anim. Sci. 85:389-399.

SAS Institute. 2002. User's Guide: Statistics, Version 9.1 Edition. SAS Inst., Inc., Cary, NC.

Shaver, R. D., and M. A. Bal. 2000. Effect of dietary thiamin supplementation on milk production by dairy cows. J. Dairy Sci. 83:2335-2340.

Steinberg, W., and W. Kaufmann. 1977. Untersuchungen zur bakteriellen Thiaminsynthese in den Vormägen von Milchkhen. Z. Tierphysiol. Tierernahr. Futtermittelkd. 39:289-301.

Stewart, C. S., and M. P. Bryant. 1988. The Rumen Bacteria. Pages 21-75 in The Rumen Microbial Ecosystem. P. N. Hobson, ed. Elsevier Science Publishing, New York, NY. 
Sutton, A. L., and J. M. Elliot. 1972. Effect of ratio of roughage to concentrate and level of feed intake on ovine ruminal vitamin B12 production. J. Nutr. 102:1341-1346.

Whitehouse, N. L., C. G. Schwab, W. R. Chesbro, K. D. Cunningham, and T. Lykos. 1991. Effects of methanol on cell lysis from its use as a washing solution for isolated microbes. J. Dairy Sci. 74(Suppl. 1):256. (Abstr.)

Williams, C. H., D. J. David, and O. Iismaa. 1962. The determination of chromic oxide in faeces samples by atomic absorption spectrophotometry. Agric. Sci. 59:381-385.
Wolin, M. J., T. L. Miller, and C. S. Stewart. 1997. Microbe-microbe interactions. Pages 467-491 in The Rumen Microbial Ecosystem. P. N. Hobson and C. S. Stewart, eds. Elsevier Science Publishing Ltd., Essex, UK.

Zimmerly, C. A., and W. P. Weiss. 2001. Effects of supplemental dietary biotin on performance of Holstein cows during early lactation. J. Dairy Sci. 84:498-506.

Zinn, R. A., F. N. Owens, R. L. Stuart, J. R. Dunbar, and B. B. Norman. 1987. B-Vitamin supplementation of diets for feedlot calves. J. Anim. Sci. 65:267-277. 